Sharif University of Technology
Scientia Iranica
Transactions A: Civil Engineering
IRAN I I IA
www.scientiairanica.com

\title{
A genetic-based model to predict maximum lateral displacement of retaining wall in granular soil
}

\author{
A. Johari ${ }^{a, *}$, A.A. Javadi ${ }^{b}$ and H. Najafic \\ a. Department of Civil and Environmental Engineering, Shiraz University of Technology, Shiraz, Iran. \\ b. Computational Geomechanics Group, College of Engineering, Mathematics and Physical Sciences, University of Exeter, Exeter, \\ $U K$. \\ c. Department of Civil Engineering, Bushehr Graduate Azad University, Bushehr, Iran.
}

Received 19 February 2014; accepted 13 September 2015

\section{KEYWORDS}

Retaining wall; Lateral displacement; Gene expression programming; Soil-structure interaction.

\begin{abstract}
Retaining walls are one of the most common geotechnical structures. Horizontal displacement at the top of the retaining wall is an important parameter in design of retaining structures because of serviceability of the wall and adjacent structures. In this research, the Gene Expression Programming (GEP) is used for developing a model to predict this design parameter of retaining wall. The input parameters of the model consist of effective period of adjacent structure, horizontal and rocking stiffness of the foundation of adjacent structure, density, Young's modulus, and friction angle of granular soil as well as the thickness and height of retaining wall. The output of the model is maximum lateral displacement of retaining wall. A database including 240 cases, created from 3D finite element modeling of a soil-retaining wall with an adjacent steel structure modeled as surcharge, is employed to develop the model. Comparison of the GEP-based model predictions with the simulated data indicates a very good performance and ability of the developed models in predicting maximum lateral displacement of retaining walls. Sensitivity and parametric analyses are conducted to verify the results. It is shown that soil density is the most influential parameter in the maximum lateral displacement of retaining wall.
\end{abstract}

(C) 2016 Sharif University of Technology. All rights reserved.

\section{Introduction}

Excavation adjacent to structures is a common geotechnical engineering practice in urban areas. Several retaining structures, such as soldier pile, soil nailing, retaining wall, and bored pile, are designed by geotechnical engineers for supporting the walls of excavation. A safe and economical design requires adequate knowledge about different aspects of behavior of retaining structures, such as their deformation. For this purpose, 3D numerical modeling of soil-retaining structures can be useful for better understanding of these behav-

*. Corresponding author. Mobile: +989173144386

E-mail address: johari@sutech.ac.ir (A. Johari) iors. In this research, 3D finite element modeling of soil-retaining walls (as the most common retaining structures) is used for predicting the maximum lateral displacement of this type of structures.

There have been many attempts to model the behavior of retaining walls in $2 \mathrm{D}$ and $3 \mathrm{D}$ including or neglecting the soil-retaining structure interaction effects. The existing methods can be categorized into numerical, analytical, experimental, and artificial intelligence methods. Many research works in these categories are summarized in the following:

Numerical method: The first systematic numerical method to analyze the Soil Structure Interaction (SSI) of retaining wall behavior was presented by Clough and 
Duncan $[1,2]$ and Duncan and Clough [3] by the finite element method. These investigators used a hyperbolic constitutive relationship to model the behavior of a backfill, and extended it to model the behavior of the wall-to-soil interfaces. They observed the importance of modeling the different stages of construction of the wall and placement of the backfill in the SSI analysis. Ebeling et al. [4] performed a comparison between results from conventional equilibrium and finite element analyses of several hypothetical gravity walls founded on rock. Their analyses were performed considering the stages of the backfill placement incorporated in Clough and Duncan [2]. They concluded that the magnitude of the downdrag force is significantly affected by the concrete-to-backfill and rock-to-backfill shear stiffness values. Goh [5] performed finite element analyses to investigate the effects of subsoil stiffness, wall stiffness, and wall roughness on the lateral earth pressure for concrete cantilever retaining walls, and proposed a modified earth pressure distribution.

Using an explicit finite difference code, Benmebarek et al. [6] investigated the increase in the passive earth pressures due to the decrease in the wall breadth in a 3D model. Ebeling et al. [7] and Ebeling et al. [8] presented the results of extensive SSI analysis for the soil founded Red River Lock and Dam No. 1. A reinforced soil berm was recommended, among other alternatives, as a solution to the problems induced by siltation of the lock. They also noted that conventional equilibrium analyses are inadequate for the design of this type of structure.

Experimental method: Ebeling et al. [9] performed experimental analysis on several gravity walls founded on rock. They found that conventional equilibrium analyses are very conservative because they do not account for the stabilizing effect of the downdrag forces generated by the settlement of the backfill. Huang and Luo [10] arranged several experiments on cantilever wall models to investigate the behavior of soil-retaining walls on deformable foundations. They found that the measured values of the coefficient of lateral pressure increased significantly with a decrease in subgrade stiffness.

Analytical method: Filz and Duncan [11] presented a theory to quantify the downdrag force on the back of nonmoving retaining walls. Filz et al. [12] presented a simplified method for incorporating downdrag forces in conventional analyses of nonmoving retaining walls. Caltabianoa et al. [13] investigated the static and seismic sliding limit equilibrium conditions of retaining walls. Ghanbari and Taheri [14] used an analytical method for calculating active earth pressure in reinforced retaining walls subject to a line surcharge. Conti and Viggiani [15] developed a new limit equilibrium method for the pseudostatic design of embedded cantilevered retaining walls.

Artificial intelligence method: Yildiz et al. [16] developed an artificial neural network model for predicting the total lateral thrust and its point of application on rigid retaining walls due to finite surface strip loads.

Gene expression programming [17] is a branch of artificial intelligence and a recent extension to Genetic Programming (GP) that develops computer programs of different sizes and shapes encoded in linear chromosomes of a fixed length. The main advantage of the GP-based approaches over the regression and other soft computing techniques is their ability to generate prediction equations without assuming the prior form of the existing relationship. There have been some scientific efforts directed at applying GEP to a number of civil engineering problems (e.g. [18-27]). The main objectives of this paper are to:

- Investigate the feasibility of using gene expression programming to find the relationship between maximum lateral displacements of retaining wall with stiffness of adjacent structure, horizontal and rocking stiffness of foundation of adjacent structure, density, Young's modulus, and friction angle of granular soil as well as the thickness and height of retaining wall;

- Assess and evaluate the prediction capabilities of the GEP-based model using 3D finite element modeling data, not exposed to the model during its development;

- Carry out sensitivity analysis and parametric study using the developed GEP model.

\section{Gene expression programming}

Gene expression programming is an evolutionary algorithm for learning the most fit computer programs by means of artificial evolution. It incorporates both the simple, linear chromosomes of fixed length similar to Genetic Algorithms (GA) and the ramified structures of different sizes and shapes similar to the parse trees of genetic programming [28].

Its behavior forms a metaphor of the processes of evolution in nature. GEP, similar to GA and GP, initializes a population that compounds the random members known as chromosomes. Afterwards, fitness of each chromosome is evaluated with respect to a target value. The principle of Darwinian natural selection is used to select and reproduce "fitter" programs. The process continues until a best solution for that problem is reached.

In GEP application, the chromosome can have one or more genes. The gene contains two types of information. The first type is stored in the head of the gene containing the information which is used in 
producing the overall GEP model. The head contains some of the functions from the pre-selected function set ' $\mathrm{F}$ ' along with some terminals from the terminal set ' $\mathrm{T}$ '. The second type is stored in the tail and contains only terminals. The tail contains information that can be used in generating future GEP models. The arrangement of functions and terminals in head and tail of a GEP gene is called its structural architecture. Gens can be linked to each other by plus, minus, product, and division. Plus linking function usually produces better fitness. It is only in recent years that GEP has found its applications in geotechnical engineering [18-27].

\section{Finite element modeling}

To develop a database including SSI effects, several 3D soil-retaining wall structures with surcharge adjacent to the excavation were modeled using the Finite Element (FE) software, ABAQUS. The ABAQUS model was validated against Plaxis and hand calculations for a number of simple retaining structures. Below a brief introduction is given to the modeling procedure:

- Surcharge: Two 6-storey and 8-storey steel structures, with a plan shown in Figure 1, were selected and modeled as the non-uniform surcharge adjacent to the excavation. The modeled structures had rigid connections and a mat foundation with $1.0 \mathrm{~m}$ thickness. The structures were designed by ETABS for gravity loading. As ABAQUS is not a designing

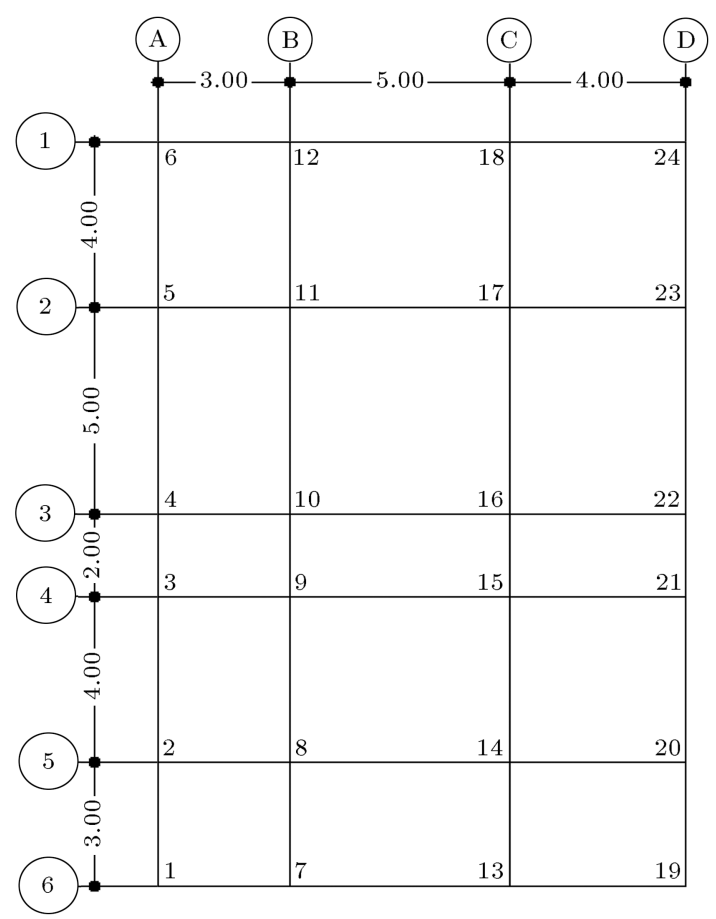

Figure 1. Plan of the structures used in finite element modeling.

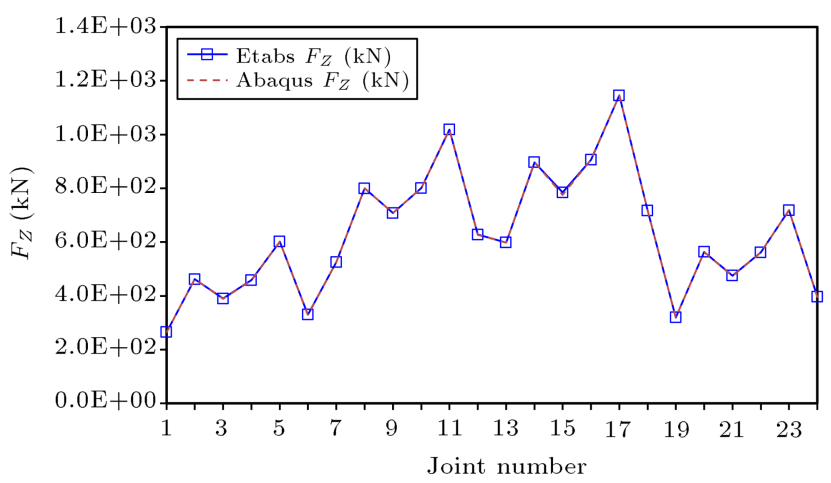

Figure 2. Comparison of vertical reactions of the 6 -storey steel structure determined by ABAQUS and ETABS (without considering SSI).

software, the structures with fixed bases were first designed by ETABS and then used in ABAQUS modeling. The structures were also analyzed in ABAQUS and comparison of vertical reactions from ETABS and ABAQUS was made for verification of the ABAQUS model. Figure 2 shows this comparison for the 6-storey structure.

The positions of structural elements (e.g. the span of columns) and their stiffness can change the distribution of the surcharge (the stresses under foundation). To include this effect, the effective period of structure was calculated based on the design code FEMA 450 [29] and included in GEP modeling as an input parameter. These parameters for all adjacent structures are given in Table 1 . The effective period is defined as:

$$
\tilde{T}=T \sqrt{1+\frac{\bar{K}}{K_{y}}\left[1+\frac{K_{y} \bar{h}^{2}}{K_{\theta}}\right]},
$$

where:

Table 1. Basic adjacent structure effective period adopted for developing GEP Model.

\begin{tabular}{ccc}
\hline $\begin{array}{c}\text { Type of } \\
\text { structure }\end{array}$ & Soil type & $\tilde{\boldsymbol{T}}$ (sec) \\
\hline \multirow{4}{*}{ 6-story } & A & 0.8157 \\
& B & 0.7903 \\
& C & 0.7740 \\
& D & 0.7626 \\
& E & 0.7543 \\
F & 0.7478 \\
8-story & A & 1.0599 \\
& B & 1.0186 \\
& C & 0.9919 \\
& D & 0.9733 \\
& E & 0.9595 \\
& F & 0.9498 \\
\hline
\end{tabular}




$$
\bar{K}=4 \pi^{2} \frac{\bar{W}}{g T^{2}},
$$

$$
K_{y}=K_{T} \cdot 2 G(1+v) \sqrt{B L}=K_{T} E \sqrt{B L},
$$$$
K_{\theta}=K_{\phi}\left(\frac{G B L^{2}}{1-v}\right)=K_{\phi}\left(\frac{E B L^{2}}{2\left(1-v^{2}\right)}\right),
$$

$$
\begin{array}{ll}
\tilde{T} & \text { Effective period; } \\
T & \text { The fundamental period of the } \\
& \text { structure; } \\
\bar{K} & \begin{array}{l}
\text { The stiffness of the fixed-base } \\
\text { structure; }
\end{array}
\end{array}
$$

$\bar{W} \quad$ The effective gravity load of the structure, which shall be taken as $0.7 \mathrm{~W}$;

$W \quad$ The weight of structure with fixed base;

$\bar{h} \quad$ The effective height of the structure, which shall be taken as 0.7 times the total height;

$K_{y} \quad$ The lateral stiffness of the foundation;

$K_{\theta} \quad$ The rocking stiffness of the foundation;

$K_{\phi}, K_{T} \quad$ The coefficients that can be defined using specific curves in FEMA 450;

$g \quad$ Acceleration due to gravity;

$G \quad$ Shear modulus;

$v \quad$ Passion ratio;

$B \quad$ Width of foundation;

$L \quad$ Length of foundation;

E Young's modulus.

- Soils: Six granular soils with their properties, such as density, Young's modulus, and friction angle that were used in this modeling, are shown in Table 2. They are sorted from weaker to stronger soil (A to F) in this table. The Mohr-Coulomb model was selected to describe the soil behavior.

Table 2. Basic soil properties adopted for developing GEP Model.

\begin{tabular}{cccc}
\hline \multirow{2}{*}{$\begin{array}{c}\text { Soil } \\
\text { type }\end{array}$} & $\begin{array}{c}\boldsymbol{\rho} \\
\left(\mathbf{k g} / \mathbf{m}^{3}\right)\end{array}$ & $\begin{array}{c}\boldsymbol{E} \\
\left(\mathbf{k N} / \mathbf{m}^{2}\right)\end{array}$ & $\begin{array}{c}\boldsymbol{\phi} \\
(\mathbf{d e g} .)\end{array}$ \\
\hline A & 1700 & 40000 & 32 \\
B & 1800 & 52000 & 34 \\
C & 1900 & 64000 & 36 \\
D & 2000 & 76000 & 38 \\
E & 2100 & 88000 & 40 \\
F & 2200 & 100000 & 42 \\
\hline
\end{tabular}

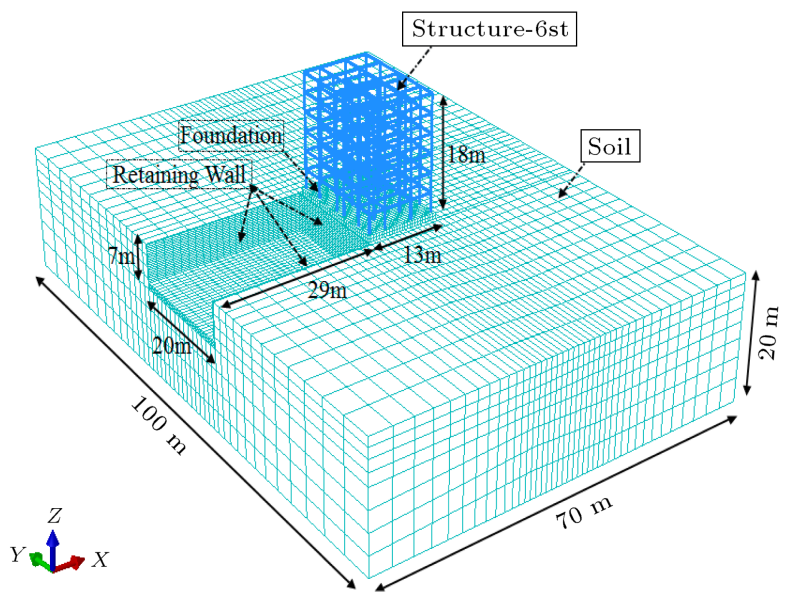

Figure 3. Global modeling by ABAQUS.

Table 3. Basic wall characteristics adopted for developing GEP Model.

\begin{tabular}{cc}
\hline $\boldsymbol{h}(\mathbf{m})$ & $\boldsymbol{t}(\mathbf{m})$ \\
\hline 3.0 & 0.25 \\
4.0 & 0.30 \\
5.0 & 0.35 \\
6.0 & 0.40 \\
& 0.45 \\
\hline
\end{tabular}

- Retaining wall: For retaining the wall of excavation, a wall connected to the adjacent foundation was used (see Figure 3). The height of the retaining wall is always $1.0 \mathrm{~m}$ less than the depth of excavation because of the $1.0 \mathrm{~m}$ thickness of the foundation. Table 3 shows the basic characteristics of the retaining wall in the finite element modeling. Different components of the FE model are shown in Figure 4.

Figure 5 shows typical results of modeling for lateral deformation of the retaining wall. Figure 6 shows the vertical foundation deformation. Figure 7 shows the horizontal displacement of the retaining wall in different soils. It can be seen that the lateral displacement decreases as the strength of the soil increases (from $\mathrm{A}$ to $\mathrm{F}$ ). Figure 8 demonstrates the horizontal displacement of the retaining wall for all lengths of walls in different soils. It is clear that the lateral displacement decreases as the strength of the soil increases (from A to $\mathrm{F}$ ).

\section{Database}

A database consisting of the results of 240 threedimensional finite element models of soil-retaining wall systems with an adjacent steel structure modeled as surcharge was used to train and test the GEP model. Usually, 70 to $80 \%$ of database is used for training while the remaining 30 to $20 \%$ of data is used for testing 


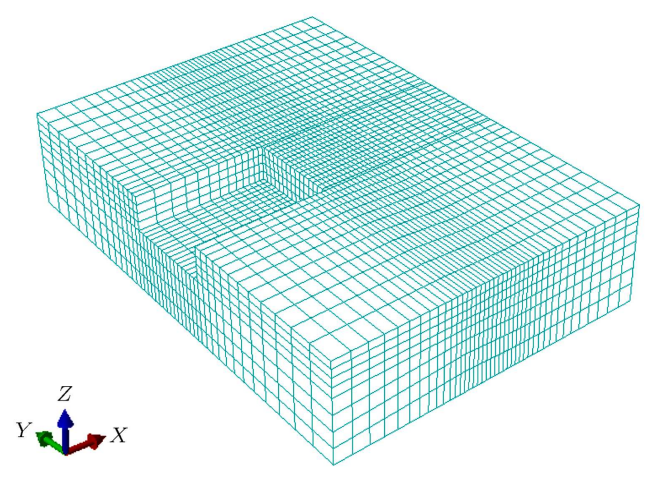

(a) Soil and excavation modeling

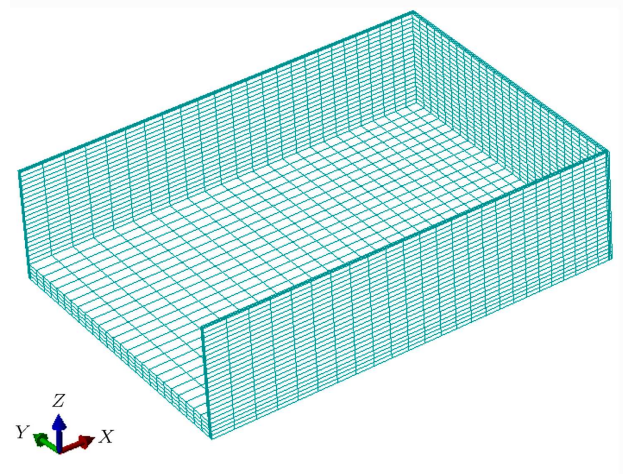

(c) Retaining wall and foundation modeling

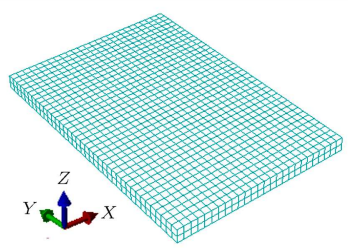

(b) Steel structure foundation modeling

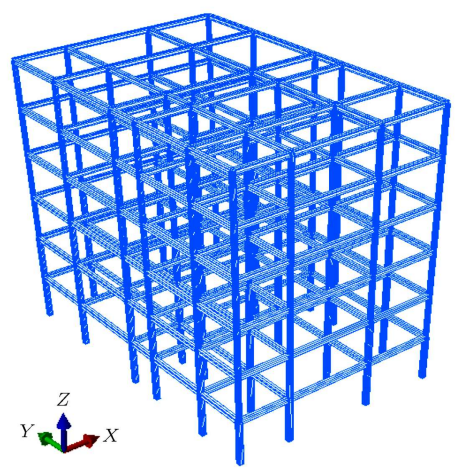

(d) 6-storey structure modeling

Figure 4. The components of the FE model.

Table 4. Basic range for input and output model parameters.

\begin{tabular}{|c|c|c|c|}
\hline \multicolumn{3}{|c|}{ Parameters } & Range \\
\hline \multirow{6}{*}{ Input } & \multirow[b]{2}{*}{ Soil } & Density (ton $/ \mathrm{m}^{3}$ ) & $17.0-22.0$ \\
\hline & & Young's modulus $\left(\mathrm{kN} / \mathrm{m}^{2}\right)$ & $40000-100000$ \\
\hline & & Friction angle (degree) & $32.0-42.0$ \\
\hline & Adjacent structure & Effective period (sec) & $0.7478-1.0599$ \\
\hline & \multirow{2}{*}{ Retaining wall } & Height (m) & $3.0-6.0$ \\
\hline & & Thickness (m) & $0.25-0.45$ \\
\hline Output & Retaining wall & $\begin{array}{l}\text { Maximum horizontal lateral } \\
\text { displacement }(\mathrm{mm})\end{array}$ & $0.332-35.59$ \\
\hline
\end{tabular}

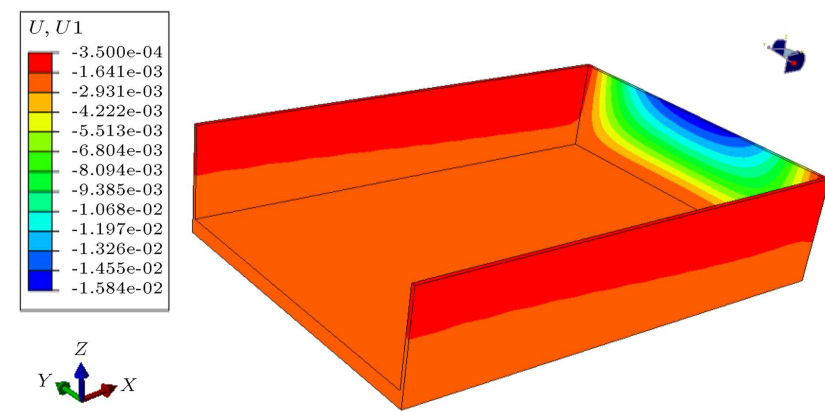

Figure 5. Lateral retaining wall deformation $(\mathrm{m})$. Excavation $h=6 \mathrm{~m}$, thickness of wall $=0.25 \mathrm{~m}$, and surcharge $=6$-storey structure. the model. In this study, the results from 180 finite element models (\%75 of total data) were employed to train the GEP model to determine the maximum lateral displacement of retaining wall. The model was further tested using the remaining 60 data sets (\%25 of total data) that were not seen by the GEP in the model development process. Table 4 indicates the range of basic input and output parameters adopted for this study. It should be noted that, like all empirical models, GEP performs best in interpretation rather than extrapolation; thus, the extreme values of the data used are included in the training set. For normalization, each component of the data set was 


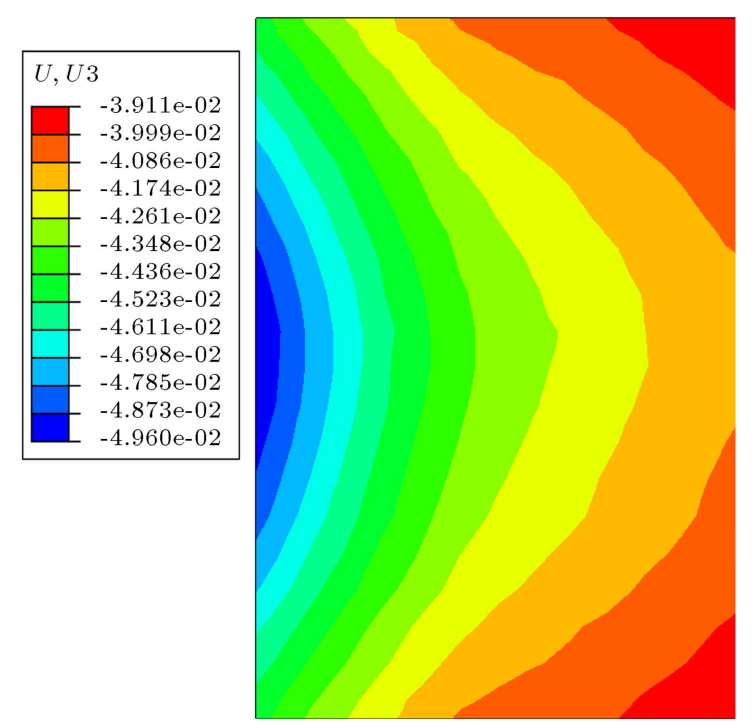

Figure 6. Foundation deformation $(\mathrm{m})$. Excavation $h=6 \mathrm{~m}$, thickness of wall $=0.25 \mathrm{~m}$, and surcharge $=$ 6-storey structure.

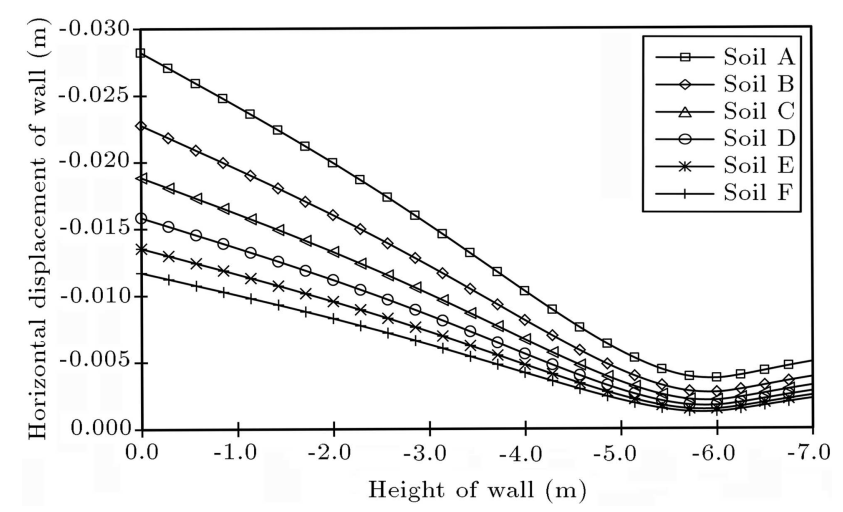

Figure 7. Horizontal displacement with respect to the height of retaining wall.

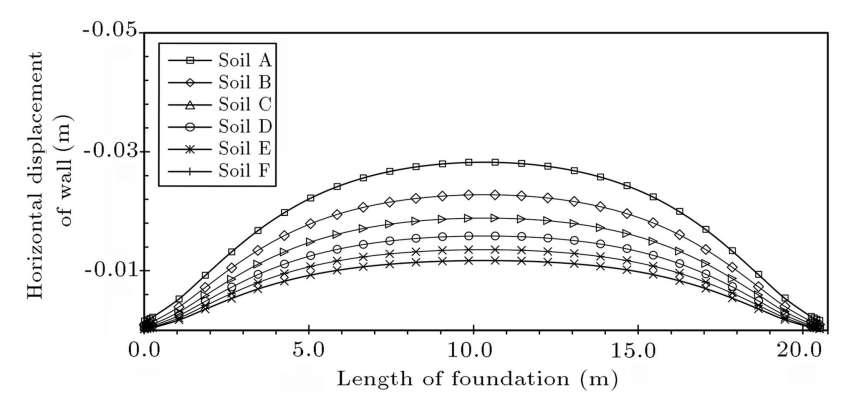

Figure 8. Horizontal displacement with respect to the length of retaining wall.

normalized to lie in an interval of $[0,1]$ using a maxmin approach.

\section{GEP modeling for predicting maximum lateral displacement of retaining wall}

A GEP software package, GeneXproTools 4.0 [30] was used in this study to perform symbolic regression to find a relationship for maximum lateral displacement of retaining wall. Six independent parameters, namely stiffness of adjacent structure, horizontal and rocking stiffness of foundation of adjacent structure, density, Young's modulus, and friction angle of granular soil, thickness and height of retaining wall, were selected as the input terminals. The output terminal was the maximum lateral displacement of retaining wall.

A large number of generations were needed to find a relationship with minimum error. To find the optimum formulation, five functions, namely plus, minus, product, division, and power were used. During the evolution process, these functions are selected to improve the fitness of the solution. The selection of the best relationship was based on simplicity and its relevance to the nature of the problem, thus ensuring a simple and efficient final GEP model. Defining the chromosome structure requires the specification of the maximum number of genes per chromosome as well as the size of the gene. The size of gene is the maximum number of functions and terminals that can be stored in the head and the tail of the gene. It is normally controlled by its head size and the complexity of the problem. The results showed that the model performed better when the addition $(+)$ was used as a linking function.

The evolution process was continued until no significant changes were noticed in the model statistics (fitness value and $R^{2}$ ) and a formula with the shortest possible length was developed. In this research, for developing the model, a performance analysis for setting GEP parameters and the model development was carried out. These stages are described below.

\subsection{Performance analysis}

To set the model parameters, a performance analysis was undertaken. In GEP, values of the parameters have significant influence on the fitness of the output model. These include the number of chromosomes, number of genes, gene's head size, and the rate of genetic operators. This approach involved using different settings and conducting runs in steps. During each step, runs were carried out and the values of one of the above-mentioned parameters were varied, whereas the values of the other parameters were kept constant. The runs were stopped after a hundred generations, which were found sufficient to evaluate fitness of the output. At the end of each run, the Mean Squared Errors (MSE) for both training and testing sets were recorded in order to identify the values that give the least MSE. When the output had the same error in different generations for the training data set, the generation with lower error was selected for the testing data set. Typical results of performance analysis for developing maximum horizontal displacement model of wall are shown in Figures 9 and 10. 


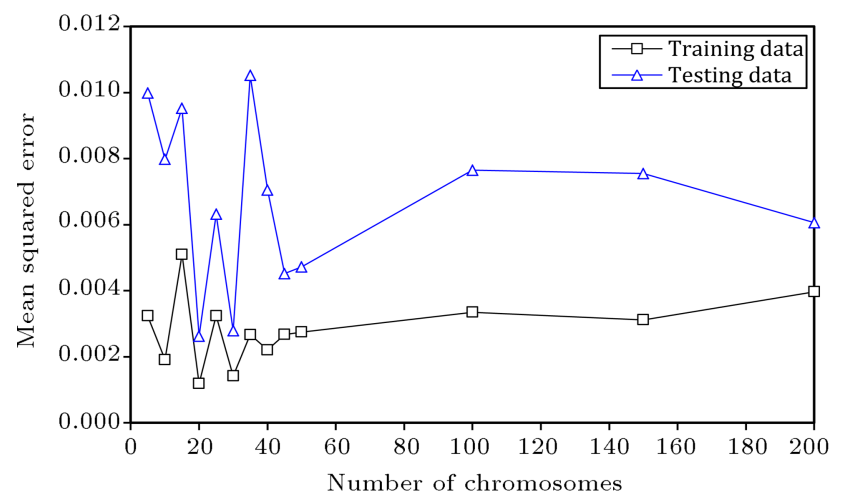

Figure 9. Effect of number of chromosomes on the performance of the GEP model (selected value $=20$ chromosomes).

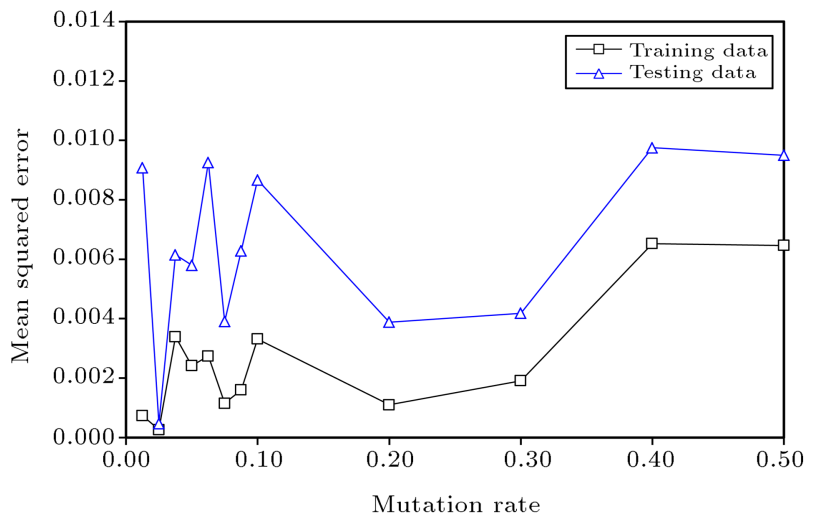

Figure 10. Effect of mutation rate on the performance of the GEP model (selected value $=0.025$ ).

In the first step, the number of chromosomes was determined. Figure 9 shows that the model had the best performance when the number of chromosomes was 20. This value corresponds to the least MSE for the training sets. Figures 10 present the influence of the rates of the genetic operator, mutation on the performance of the GEP model. It can be seen that the GEP model performs best when mutation and gene recombination rates are 0.05 . The final parameters involved in the GEP predictive algorithm are shown in Table 5.

Table 5. Input parameters used for the GEP models.

\begin{tabular}{ll}
\hline Parameters & $\begin{array}{c}\text { Achieved functions, } \\
\text { values, and rates }\end{array}$ \\
\hline Linking function & Addition $(+)$ \\
Function set &,,$+- \times, \div$, power \\
Number of chromosomes & 20 \\
Number of genes & 5 \\
Gene head size & 7 \\
Recombination rate & 0.2 \\
Mutation rate & 0.025 \\
\hline
\end{tabular}

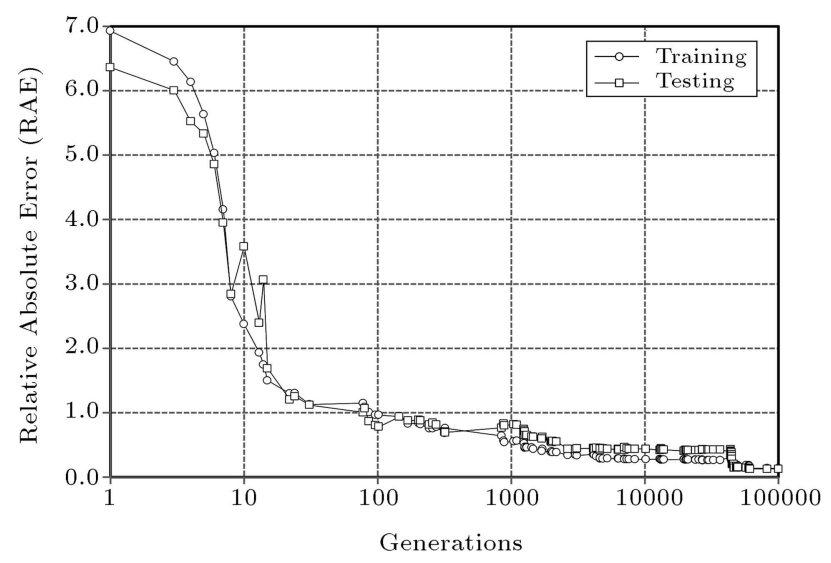

Figure 11. Variation of error measured during training and testing generations.

\subsection{Model development}

After finding the best GEP setting parameters, the short, simple, and most accurate model (optimum formulation) was obtained by conducting several runs using these parameters. For this purpose, the chromosomes corresponding to the formulation with minimum error was compared with the actual test results. In this process, the performance was also checked using sum of absolute differences between the predicted and actual values of the maximum lateral displacement. The average relative error is defined as:

Average relative absolute error $=$

$$
\frac{1}{N} \sum_{i=1}^{N}\left|\frac{A_{i}-P_{i}}{A_{i}}\right| \times 100 .
$$

Iterations continued until this error measure did not decrease appreciably. Figure 11 indicates the variation of average relative absolute error during the best model development for maximum horizontal displacement. The training error of the model dropped from 6.92 in the first generation to about 0.10 after 100,000 generations and, in testing, the error dropped from 6.34 to about 0.12 in the same number of generations.

As mentioned earlier, one of the advantages of the GEP technique is that the relationship between the inputs and corresponding output is automatically constructed in the Expression Trees (ET). In this research, the appropriate ETs (ET1 to ET4) that are linked to each other with addition to produce the final model are presented in Figure 12 for the maximum lateral displacement.

The trees are easily formulated into a mathematical equation for maximum lateral displacement as follows:

$$
\begin{aligned}
U_{\max }= & \rho-0.187 . h^{1.5}+\frac{h^{1.33}}{t+1.032+\tan (\phi)}-E \\
& +(t+E-5.064)^{4} \times 0.000275 . \tilde{T},
\end{aligned}
$$




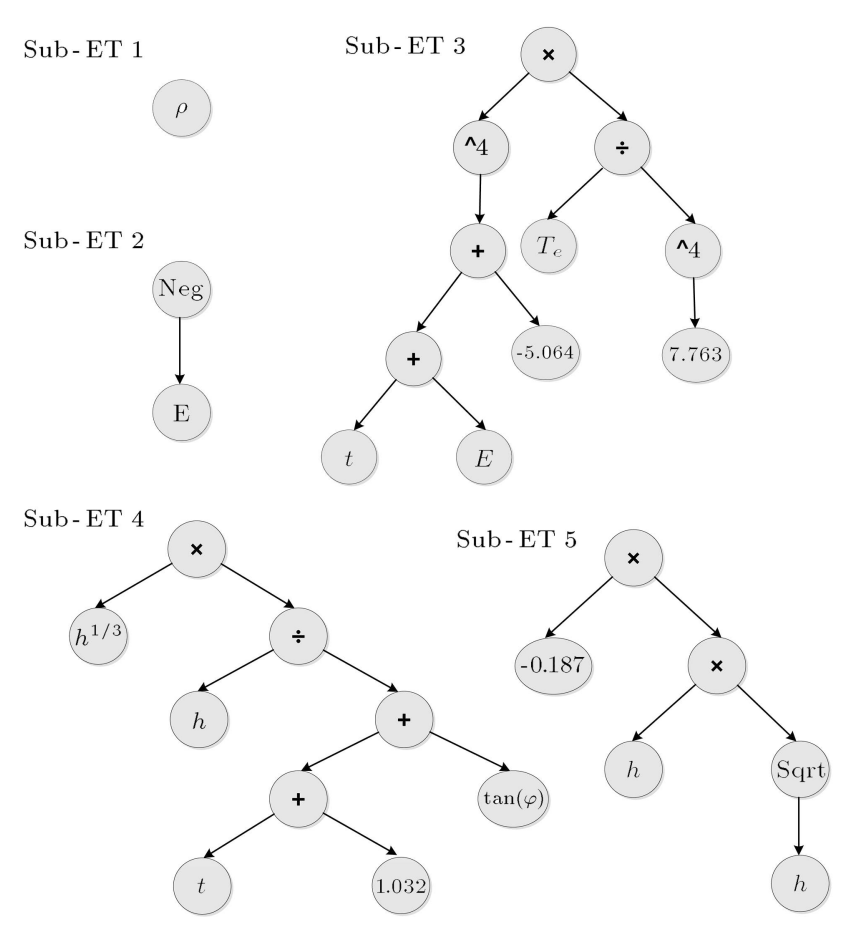

Figure 12. Expression Tree (ET) of the developed GEP mode.

where:

$U_{\max } \quad$ Maximum horizontal displacement of retaining wall;

$\rho \quad$ Soil density;

$h \quad$ Height of retaining walls;

$t \quad$ Thickness of retaining walls;

$\phi \quad$ Friction angle;

E Young's modulus;

$\tilde{T} \quad$ Effective period.

\section{Results and discussion}

Eq. (6) was used to predict the maximum lateral displacement of retaining wall for all 180 cases of the training set and 60 cases in the testing set. Figures 13 and 14 compare the predicted maximum horizontal displacements of retaining wall with the actual data for training and testing cases. The results show a good correlation between the predictions made using the GEP formulation and the actual data both for modeling and testing data sets. In these figures, the correlation coefficient $R^{2}$ is used to compare the results, given by:

$$
R^{2}=1-\frac{\sum_{i=1}^{n}\left(A_{i}-P_{i}\right)^{2}}{\sum_{i=1}^{n}\left(A_{i}-\bar{A}_{i}\right)^{2}},
$$

where $A_{i}$ and $P_{i}$ are, respectively, the actual and predicted output values for the $i$ th output; $\bar{A}_{i}$ is the

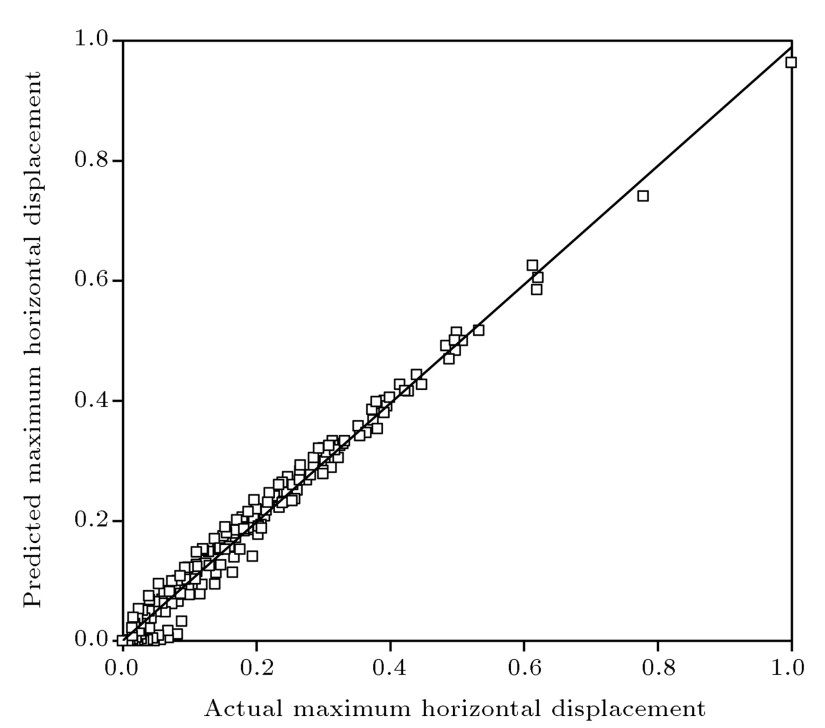

Figure 13. Actual versus predicted maximum horizontal displacement for training data, $R^{2}=0.982$.

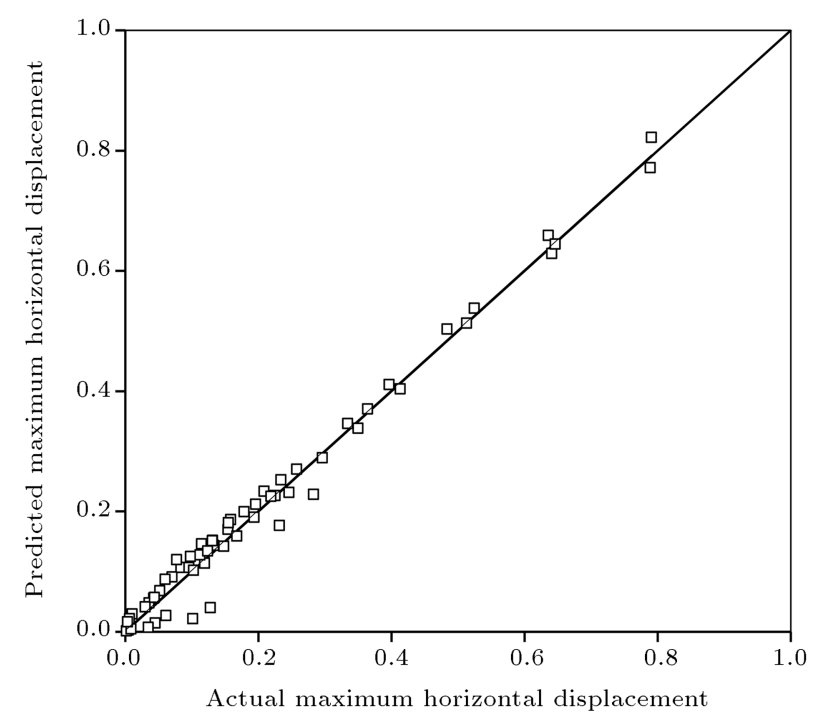

Figure 14. Actual versus predicted maximum horizontal displacement for testing data, $R^{2}=0.984$.

average of the actual outputs; and $n$ is the number of data points.

\subsection{Sensitivity analysis}

To evaluate the model's response to changes in input parameters, a sensitivity analysis was carried out. For this purpose, all input parameters (the friction angle $(\phi)$, Young's modulus $(\underset{\sim}{E})$, density $(\gamma)$, effective period of adjacent structure $(\tilde{T})$, height $(h)$, and thickness $(t)$ of retaining wall) were considered. To evaluate the influence of each input parameter on the maximum lateral displacement of retaining wall, the mean value of the input parameter was increased approximately $20 \%$ while the ranges of the other input parameters were kept constant. The results are given in Table 6 . In this table, negative change means reduction and positive 
Table 6. The change in retaining wall designing parameters corresponding to $20 \%$ increase in the mean value of the input parameters.

\begin{tabular}{ccccccc}
\hline Parameter & $\begin{array}{c}\text { Friction } \\
\text { angle }\end{array}$ & $\begin{array}{c}\text { Young's } \\
\text { modulus }\end{array}$ & $\begin{array}{c}\text { Soil } \\
\text { density }\end{array}$ & $\begin{array}{c}\text { Height of } \\
\text { retaining wall }\end{array}$ & $\begin{array}{c}\text { Thickness of } \\
\text { retaining wall }\end{array}$ & $\begin{array}{c}\text { Effective } \\
\text { period }\end{array}$ \\
\hline $\begin{array}{c}\text { Maximum horizontal } \\
\text { displacement }\end{array}$ & -17.06 & -24.35 & 35.60 & 23.57 & -14.56 & 11.48 \\
\hline
\end{tabular}

means increase in the maximum lateral displacement of retaining wall. It is shown that the maximum lateral displacement of retaining wall decreases with increase in friction angle, Young's modulus, and thickness of retaining wall. Furthermore, Table 6 shows that with an increase in density, effective period and height of retaining wall and the maximum lateral displacement of wall decrease. This table shows that the soil density plays an important role in determining the maximum lateral displacement of retaining wall.

\subsection{Parametric analysis}

For further verification of the proposed GEP models, a parametric analysis was performed. The main goal was to find how each parameter affects the maximum lateral displacement of retaining wall. Figures 15 to 20 present the predicted values for the maximum lateral displacement as a function of each parameter where others were constant. For this purpose, a data set with the following characteristics was selected for training and testing as given in Table 7 .

The results of the parametric analysis indicate

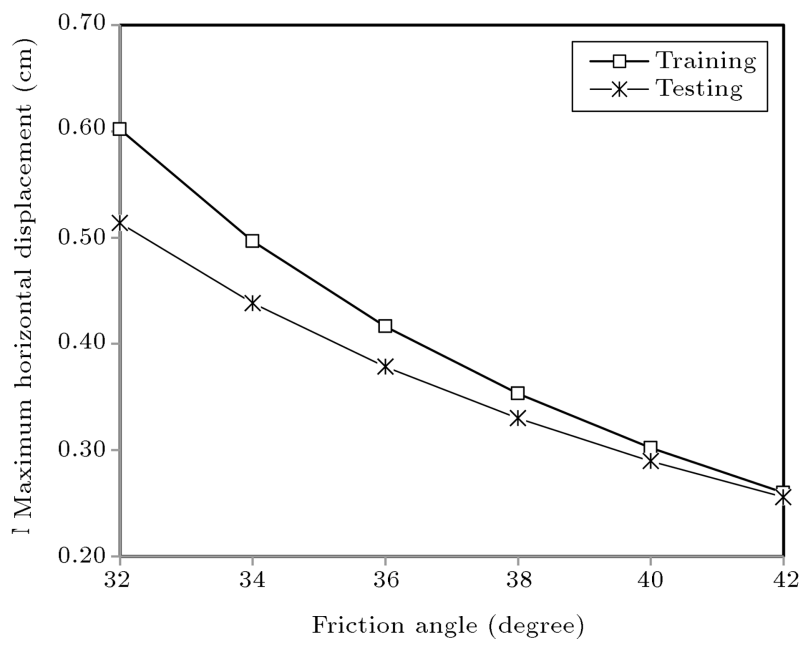

Figure 15. Parametric analysis of output model with respect to friction angle.

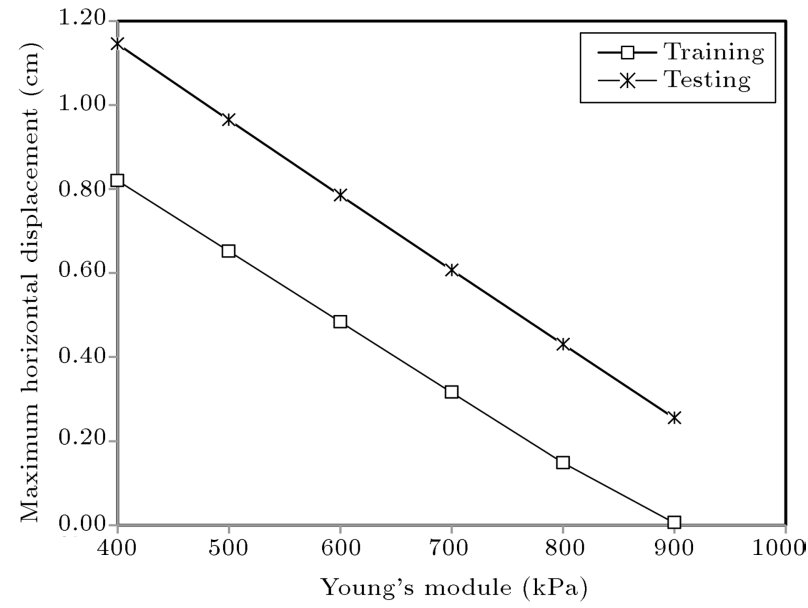

Figure 16. Parametric analysis of output model with respect to Young's modulus.

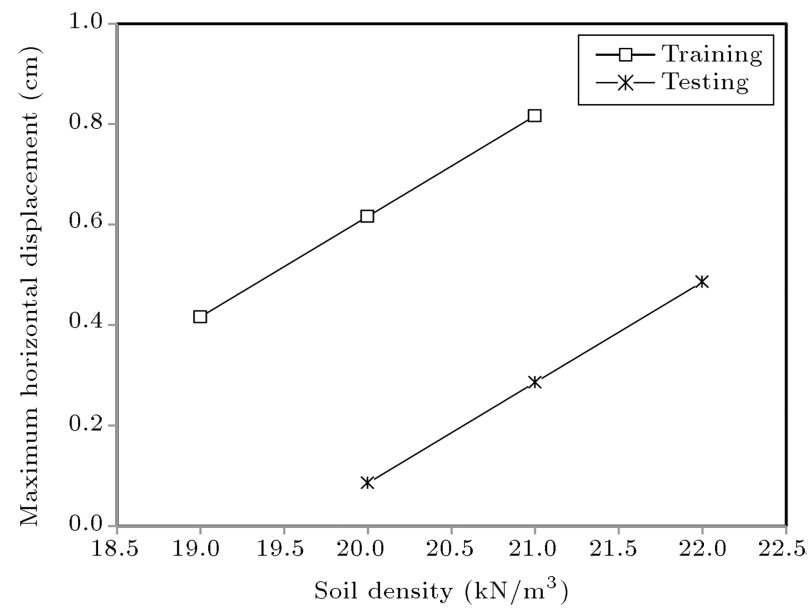

Figure 17. Parametric analysis of output model with respect to soil density.

that, as expected, the maximum lateral displacement of retaining wall continuously increases with increasing soil density, height of retaining wall, and effective period of adjacent structure. The maximum lateral displacement of retaining wall decreases when the

Table 7. Selected data from training and testing data sets for parametric analysis.

\begin{tabular}{ccccccc}
\hline Parameter & $\begin{array}{c}\text { Friction } \\
\text { angle } \\
(\mathbf{d e g r e e})\end{array}$ & $\begin{array}{c}\text { Young's } \\
\text { modulus } \\
\left(\mathbf{k N} / \mathbf{m}^{2}\right)\end{array}$ & $\begin{array}{c}\text { Soil } \\
\text { density } \\
\left(\mathbf{t o n} / \mathbf{m}^{3}\right)\end{array}$ & $\begin{array}{c}\text { Height of } \\
\text { retaining } \\
\text { wall } \mathbf{( m )}\end{array}$ & $\begin{array}{c}\text { Thickness of } \\
\text { retaining } \\
\text { wall } \mathbf{( m )}\end{array}$ & $\begin{array}{c}\text { Effective } \\
\text { period } \\
(\mathbf{s e c})\end{array}$ \\
\hline Training & 36.0 & 640 & 19.0 & 0.30 & 6 & 0.774 \\
Testing & 40.0 & 880 & 21.0 & 0.35 & 6 & 1.0186 \\
\hline
\end{tabular}




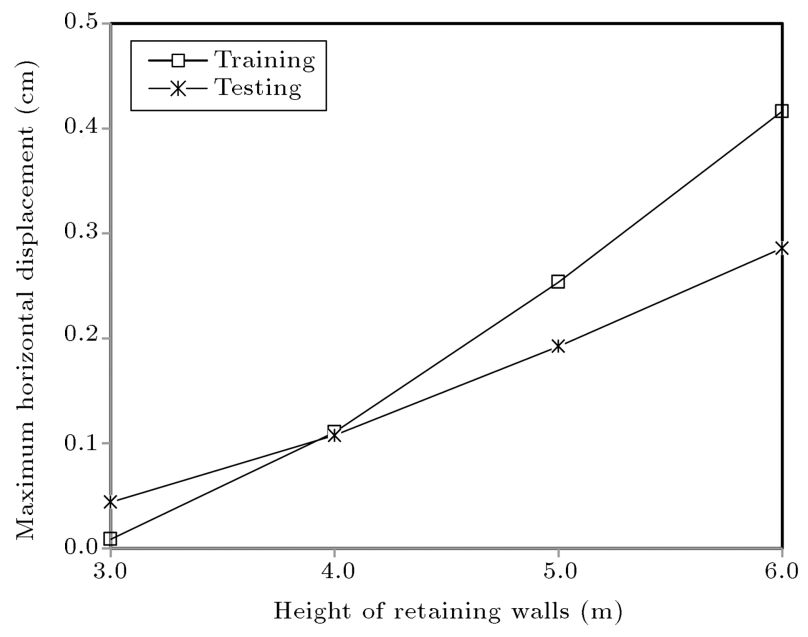

Figure 18. Parametric analysis of output model with respect to height of retaining wall.

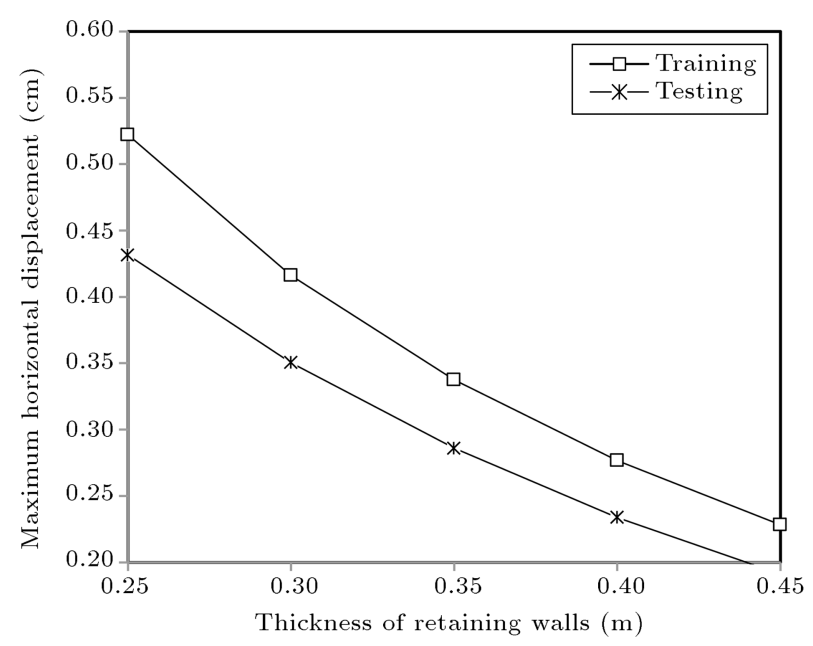

Figure 19. Parametric analysis of output model with respect to thickness of retaining wall.

friction angle, Young's modulus of soil, and thickness of retaining wall increase.

\section{Conclusion}

A model was proposed based on GEP to estimate the maximum lateral deformation of a retaining wall. The input parameters of the model include period of adjacent structure, horizontal and rocking stiffness of foundation of adjacent structure, density, Young's modulus, and friction angle of granular soil as well as the thickness and height of retaining wall. A database comprising 240 cases was developed using three dimensional finite element modeling of a soilretaining wall system, with an adjacent steel structure modeled as surcharge. The database was used to train and test the GEP model. The predictions of the model indicated a good accuracy both for the results used in the training and those used in testing. The results of

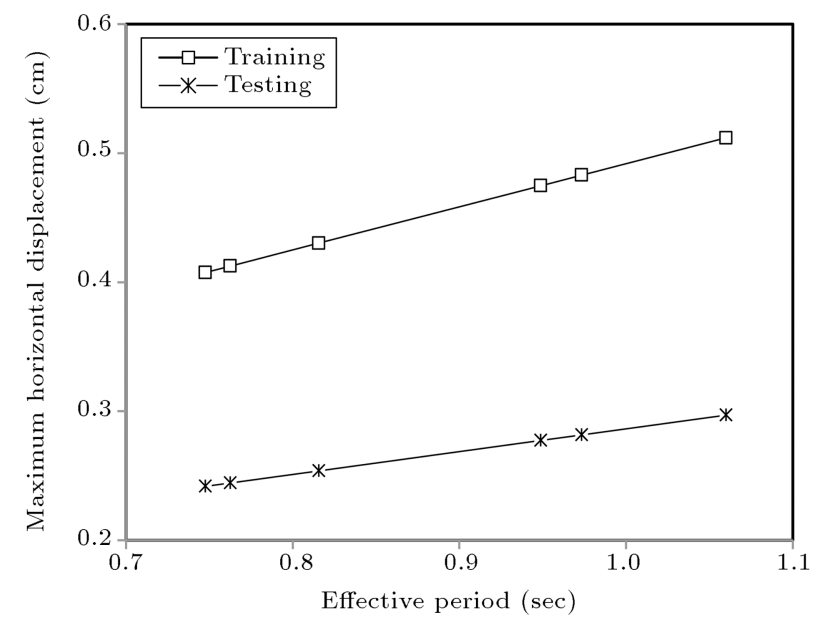

Figure 20. Parametric analysis of output model with respect to effective period.

the model predictions were compared to the actual test data and indicated its good performance for prediction of the maximum lateral displacement of retaining wall. Sensitivity analysis showed that soil density is the most influential parameter in the maximum lateral displacement of retaining wall. Furthermore, a parametric analysis showed an acceptable trend for the model with changing the input parameters.

\section{References}

1. Clough, G.W. and Duncan, J.M. "Finite element analyses of port Allen and Old River Locks", Contract Report S-69-6, U.S. Army Engineer Waterways Experiment Station, Vicksburg, MS (1969).

2. Clough, G.W. and Duncan, J.M. "Finite element analysis of retaining wall behavior", Journal of the Soil Mechanics and Foundations Division, 97(SM12), pp. 1657-73 (1971).

3. Duncan, J.M. and Clough, G.W. "Finite element analyses of Port Allen Lock", Journal of Soil Mechanics and Foundations, 97(SM8), pp. 1053-1068 (1971).

4. Ebeling, R.M., Duncan, J.M. and Clough, G.W. "Methods of evaluating the stability and safety of gravity earth retaining structures founded on rockphase 2 study", Technical Report ITL-90-7, U.S. Army Engineer Waterways Experiment Station, Vicksburg, MS (1990).

5. Goh, A.T.C. "Behavior of cantilever retaining walls", Journal of Geotechnical Engineering, 119(11), pp. 1751-1770 (1993).

6. Benmebarek, S., Khelifa, T., Benmebarek, N. and Kastner, R. "Numerical evaluation of 3D passive earth pressure coefficients for retaining wall subjected to translation", Computers and Geotechnics, 35, pp. 4760 (2008).

7. Ebeling, R.M., Mosher, R.L., Abraham, K. and Peters, J.F. "Soil structure interaction study of the Red River 
Locks and Dam No. 1 subjected to sediment loading", Technical Report ITL-93-3, U.S. Army Engineer Waterways Experiment Station, Vicksburg, MS (1993).

8. Ebeling, R.M., Peters, J.F. and Mosher, R.L. "The role of non-linear deformation analyses in the design of a reinforced soil berm at Red-River Uframe Lock No. 1", International Journal of Numerical and Analytical Methods in Geomechanics, 21, pp. 753-87 (1997).

9. Ebeling, R.M., Clough, G.W., Duncan, J.M. and Brandon, T.L. "Methods of evaluating the stability and safety of gravity earth retaining structures founded on rock", Technical Report REMR-CS-29, U.S. Army Engineer Waterways Experiment Station, Vicksburg, MS (1992).

10. Huang, C.-C. and Luo, W.-M. "Behavior of soil retaining walls on deformable foundations", Engineering Geology, 105, pp. 1-10 (2009).

11. Filz, G.M. and Duncan, J.M. "Vertical shear loads on nonmoving walls; I. Theory", Journal of Geotechnical Engineering, 123(9), pp. 856-62 (1997).

12. Filz, G.M., Duncan, J.M. and Ebeling, R.M. "Vertical shear loads on nonmoving walls; II. Applications", Journal of Geotechnical Engineering, 123(9), pp. 86373 (1997).

13. Caltabianoa, S., Casconeb, E. and Maugeric, M. "Static and seismic limit equilibrium analysis of sliding retaining walls under different surcharge conditions", Soil Dynamics and Earthquake Engineering, 37, pp. 38-55 (2012).

14. Ghanbari, A. and Taheri, M. "An analytical method for calculating active earth pressure in reinforced retaining walls subject to a line surcharge", Geotextiles and Geomembranes, 34, pp. 1-10 (2012).

15. Conti, R. and Viggiani, G.M.B. "A new limit equilibrium method for the pseudostatic design of embedded cantilevered retaining walls", Soil Dynamics and Earthquake Engineering, 50, pp. 143-150 (2013).

16. Yildizi, E., Ozyazicioglu, M.H. and Ozkan, M.Y. "Lateral pressures on rigid retaining walls: A neural network approach", Journal of Science, 23(2), pp. 201210 (2010)

17. Ferreira, C. "Gene expression programming: A new adaptive algorithm for solving problems", Complex System, 13, pp. 87-129 (2001).

18. Mollahasani, A., Alavi, A.H. and Gandomi, A.H. "Empirical modeling of plate load test moduli of soil via gene expression programming", Computers and Geotechnics, 38, pp. 281-286 (2011).

19. Allavi, A.H., Aminian, P., Gandomi, A.H. and Arabesmaeili, M. "Genetic-based modeling of uplift capacity of suction caissons", Expert Systems with Applications, 38, pp. 12608-12618 (2011).

20. Calabar, A.F. and Cevik, A. "Triaxial behavior of sand-mica mixtures using genetic programming", Expert Systems with Applications, 38, pp. 10358-10367 (2011).
21. Alkroosh, I. and Nikraz, H. "Predicting axial capacity of driven piles in cohesive soils using intelligent computing", Engineering Applications of Artificial Intelligence, 25, pp. 618-627 (2011).

22. Cevik, A. and Cabalar, A.F. "Modelling damping ratio and shear modulus of sand-mica mixtures using genetic programming", Expert Systems with Applications, 36(4), pp. 7749-7757 (2009).

23. Johari, A., Nakhaee, M. and Habibagahi, G. "Prediction of unsaturated soils effective stress parameter using gene expression programming", Scientia Iranica A, 20(5), pp. 1433-1444 (2013).

24. Ferreira, C., Gene Expression Programming: Mathematical Modeling by an Artificial Intelligence, 2nd Ed., Springer_Verlag, Germany (2006).

25. Johari, A. and Hooshmandnejad, A. "Prediction of soil-water characteristic curve using gene expression programming", International Journal of Science and Technology, Trans. Civil Engineering, 39(C1), pp. 143165 (2015).

26. Muduli, P.K. and Das, S.K. "CPT-based seismic liquefaction potential evaluation using multi-gene genetic programming approach", Indian Geotechnical Journal, 44(1), pp. 86-93 (2014).

27. Güllü, H. "Function finding via genetic expression programming for strength and elastic properties of clay treated with bottom ash", Engineering Applications of Artificial Intelligence, 35, pp. 143-157 (2014).

28. Ferreira, C. "What is GEP? From GeneXprotools Tutorials-A", Gepsoft Web Resource. http://www. gepsoft.com/tutorial002.htm Retrieved 23rd August (2010).

29. Building Seismic Safety Council (BSSC), NEHRP recommended provisions for seismic regulation for new buildings and other structures. FEMA 450-1, Federal Emergency Management Agency, Washington, DC. (2003).

30. GEPSOFT, GeneXproTools, Version 4.0, Available at: http://www.gepsoft.com (2006).

\section{Biographies}

Ali Johari is Assistant Professor at Shiraz University of Technology, Civil and Environmental Engineering Department, where he has been a faculty member since 2009. He received his $\mathrm{BSc}, \mathrm{MSc}$ and $\mathrm{PhD}$ degrees from Shiraz University in 1995, 1999, and 2006, respectively. In 2008, he was a Post-Doctoral researcher at Exeter University, where he is currently a member of research staff in Computational Geomechanics Group. His main areas of research interests are in probabilistic analysis and reliability assessment, application of intelligent systems in geotechnical engineering and unsaturated soil mechanics. He has also advised and supervised numerous geotechnical projects. 
Akbar Javadi obtained his BS and MS degrees from Tabriz University, Iran, and a PhD degree from Bradford University, UK, where he is Associate Professor of Geotechnical and Geoenvironmental Engineering and Head of the Computational Geomechanics Group. He teaches geotechnical courses at undergraduate and graduate levels, and has also supervised over $20 \mathrm{PhD}$ students and 3 postdoctoral researchers. He is a member of the British Geotechnical Society, member of the International Society of Soil Mechanics and Geotechnical Engineering (ISSMGE), graduate member of the Institution of Civil Engineers, and committee member of the UK Association of Computational Mechanics in Engineering (ACME). The results of his research have been presented in over 250 publications in international journals, book chapters, conference proceedings, and research reports.

Hadi Najafi was graduate student in Geotechnical Engineering. His research area is study on conventional soil retaining systems using finite element method, laterally loaded piles and artificial intelligence methods. At present, he is actively involved in geotechnical engineering projects and research. 